\title{
Do atypical femoral fractures in patients with prolonged alendronate treatment heal?
}

\author{
Uzun süreli alendronat tedavisi gören hastalarda femoral yetersizlik kırıkları iyileşir mi?
}

\author{
O. Şahap Atik, M.D., Akif M. Öztürk, M.D., Cemalettin Kunat, M.D., \\ Mehmet Çetinkaya, M.D., Yiğit Kaptan, M.D. \\ Department of Orthopedics and Traumatology, Medical Faculty of Gazi University, Ankara, Turkey
}

\begin{abstract}
Osteoporosis, which is a major health problem, may have an adverse impact on the economic status of the society and the quality of the life of the patients. Long-term alendronate use may cause an increased susceptibility to fractures with an increased risk of delayed union. In this article, we describe two patients on long-term alendronate therapy which were treated for atypical femoral fractures healed with surgical treatment plus calcium, vitamin D support, and alendronate discontinuation.
\end{abstract}

Key words: Atypical femoral fracture; fracture healing; prolonged alendronate therapy.

Osteoporosis, which is a major health problem, may have an adverse impact on the economic status of the society and the quality of the life of the patients. ${ }^{[1,2]}$ There are reports indicating that long-term alendronate use may cause an increased susceptibility to fractures. ${ }^{[3,4]}$ Also, recent reports have suggested that a potential complication may be delayed union after atypical femoral fracture stabilization in patients taking long-term bisphosphonate. ${ }^{[5,6]}$

This article describes two patients on long-term alendronate therapy which were treated for atypical femoral fractures healed with surgical treatment plus calcium, vitamin D support, and alendronate discontinuation.

\section{CASE REPORT}

Case 1- A 76-year-old woman was admitted with complaints of pain and swelling in her right
Osteoporoz, toplumun ekonomik durumunda ve hastaların yaşam kalitesinde olumsuz etki yaratabilen önemli bir sağlık sorunudur. Uzun süreli alendronat kullanımı, kırığa yatkınlığı ve geç kaynama riskini artırabilir. Bu yazıda uzun süredir alendronat almakta olan ve atipik femur kırıklarının cerrahi tedaviye ek olarak kalsiyum, D vitamini desteği ve alendronat alımının durdurulması ile iyileşen iki hasta bildirildi.

Anahtar sözcükler: Atipik femur kırı̆̆ı; kırık iyileşmesi; uzun süreli alendronat tedavisi.

thigh following low-energy trauma. She was on alendronate therapy for more than 10 years. Physical examination revealed mild swelling, pathologic motion and painful right thigh. Radiographs (Figures 1a, b) showed a transverse fracture with medial spike in the area of thickened cortices of femoral diaphysis. Following reduction, femoral diaphysis fracture was fixed with proximally and distally locked intramedullary nail using the image intensifier (Figures 2a, b).

The patient is pain-free and able to walk with full weight-bearing without any complications, since the first postoperative day (Figures 3-7). Dual-energy X-ray absorptiometry (DXA) revealed $\mathrm{T}$ score for lumbar spine: -2.89 and $\mathrm{T}$ score for hip: -3.55 .

Case 2- A 39-year-old woman with surgical premature menopause-induced osteoporosis was

- Received: January 26, 2014 Accepted: February 15, 2014

- Correspondence: O. Şahap Atik, M.D. Gazi Üniversitesi Tıp Fakültesi Ortopedi ve Travmatoloji Anabilim Dalı, 06500 Beşevler, Ankara, Turkey. Tel: +90 312 - 2025528 Fax: +90 312 - 2129008 e-mail: satikmd@gmail.com 

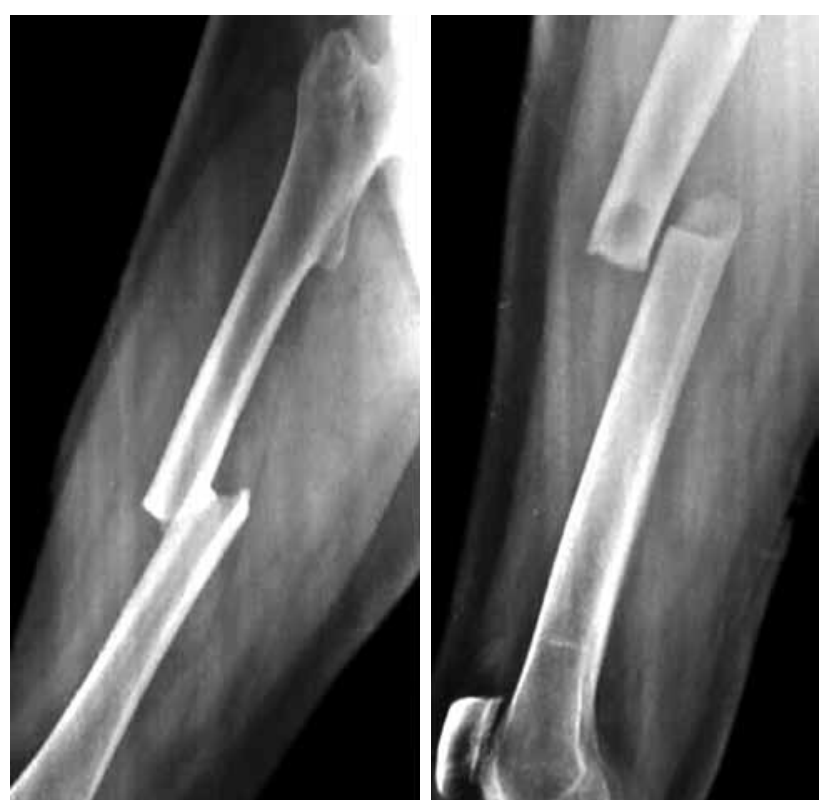

Figure 1. Anteroposterior and lateral radiograms showing atypical fracture of femoral diaphysis.

admitted with complaints of pain and swelling in her left hip following low-energy trauma. She was on alendronate therapy for eight years. Physical examination revealed a painful left hip. Radiogram showed a transverse femoral neck fracture (Figure 8). Following reduction, femoral neck fracture was fixed with three cannulated screws using the image intensifier (Figures $9 a, b$ ).

The patient is pain-free and able to walk with full weight-bearing without any complications, since

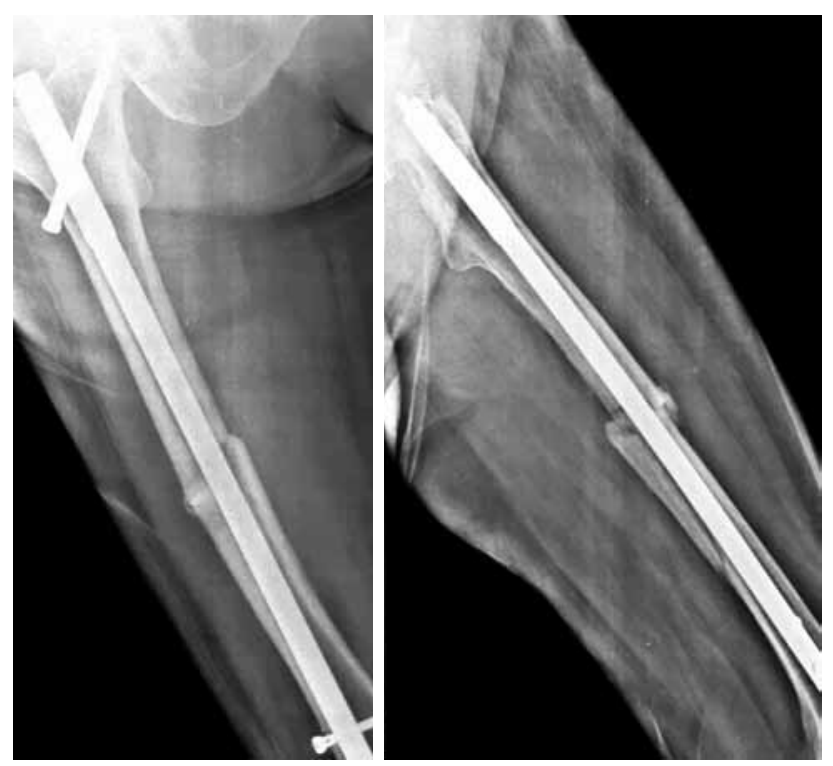

Figure 3. Postoperative anteroposterior and lateral radiograms on second month showing healing fracture of femoral diaphysis.

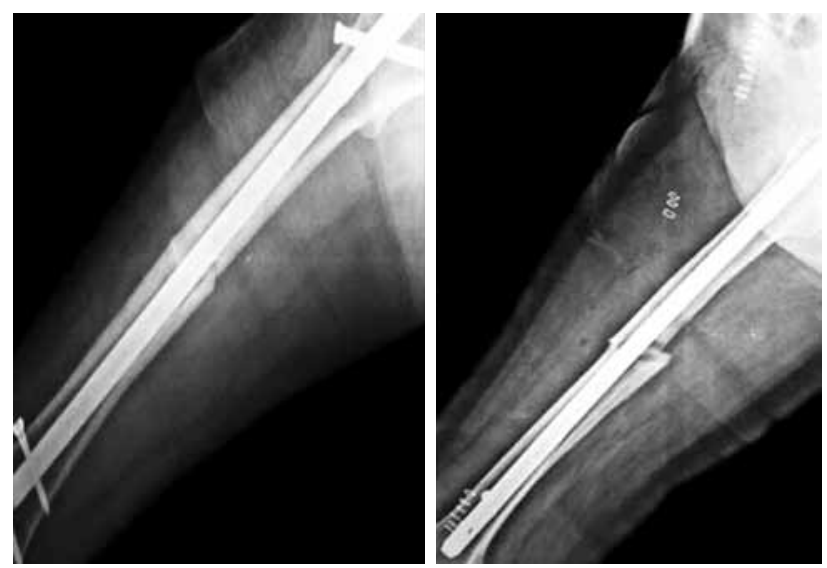

Figure 2. Postoperative anteroposterior and lateral radiograms showing atypical fracture of femoral diaphysis fixed with proximally and distally locked intramedullary nail.

the third postoperative month (Figures 10, 11). Dualenergy X-ray absorptiometry revealed $\mathrm{T}$ score for lumbar spine: -2.5 and $\mathrm{T}$ score for hip: -3.0 . We discontinued alendronate treatment in both patients and they received only calcium and vitamin D supplementation.

\section{DISCUSSION}

Increased micro-damage accumulation has been reported in women with low bone mineral densities who are treated with alendronate. ${ }^{[7]}$ Severe suppression of bone turnover, and microdamage accumulation may increase the risk of atypical fractures. Currently, some bone specialists recommend stopping alendronate intake in most patients after five years. ${ }^{[8]}$
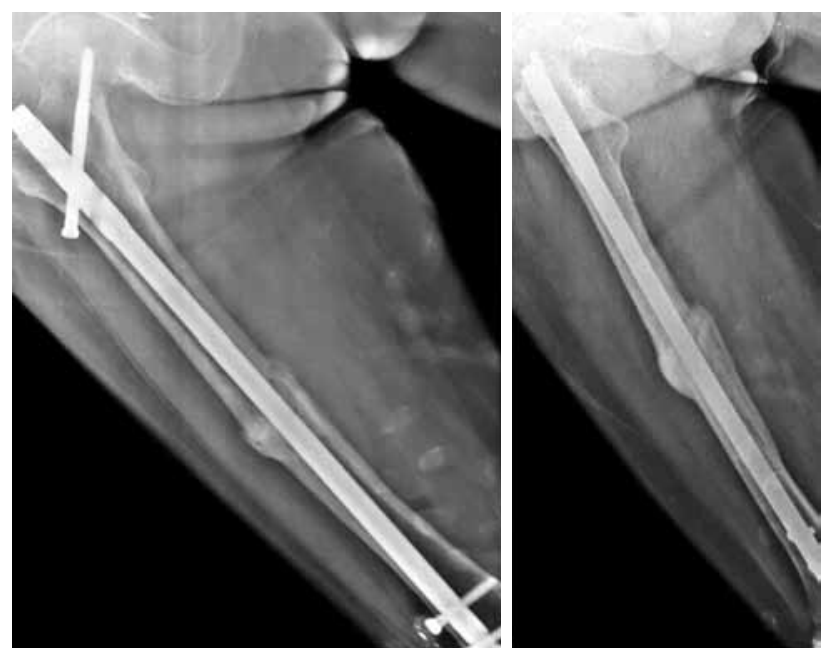

Figure 4. Postoperative anteroposterior and lateral radiograms on fifth month showing healing fracture of femoral diaphysis. 


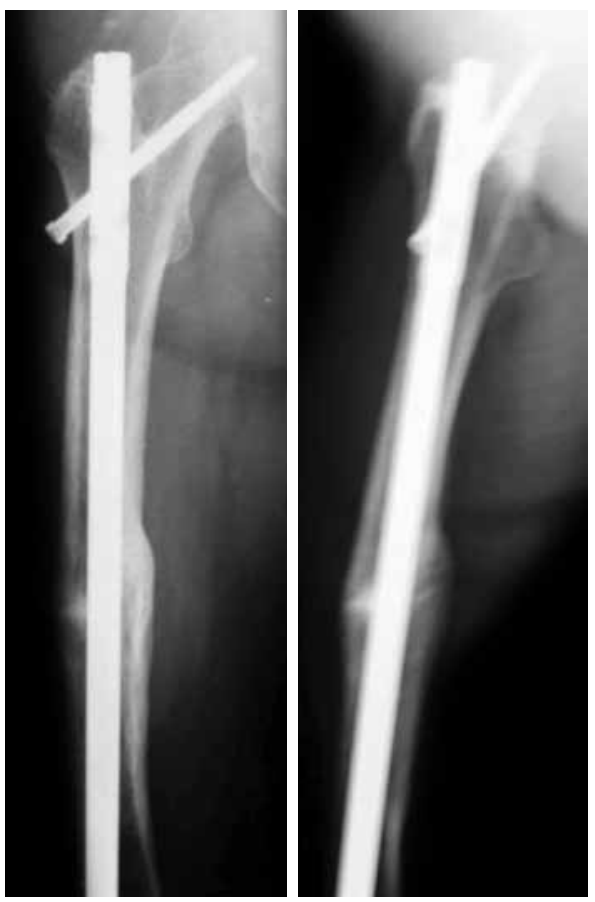

Figure 5. Postoperative anteroposterior and lateral radiograms on first year showing healing fracture of femoral diaphysis.

Atypical femoral fractures are usually atraumatic, may be bilateral, and may have delayed fracturehealing. ${ }^{[5,6,9]}$ For this reason we discontinued

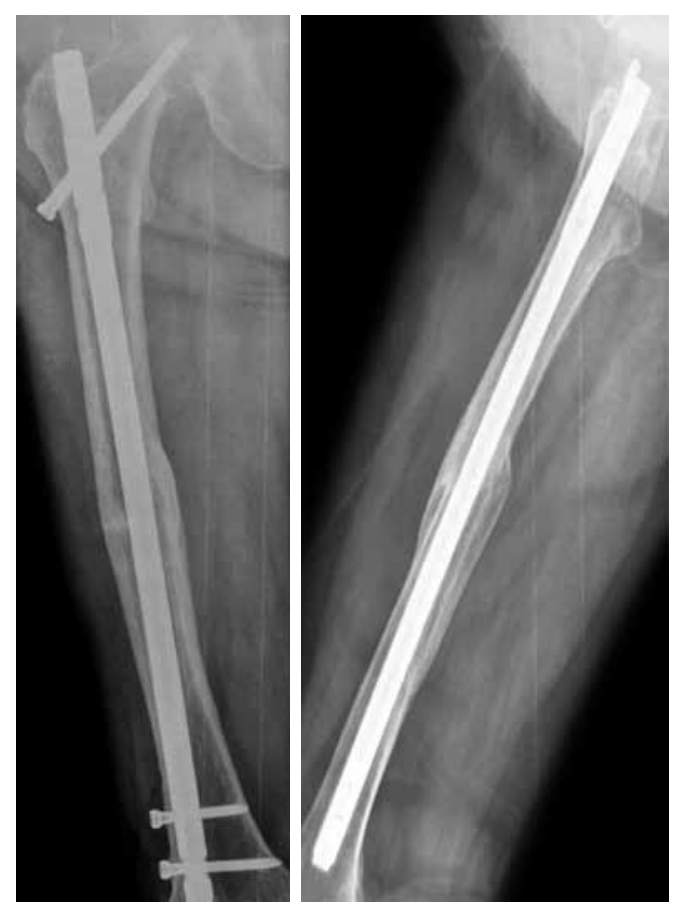

Figure 7. Postoperative anteroposterior and lateral radiograms on third year showing healing fracture of femoral diaphysis.

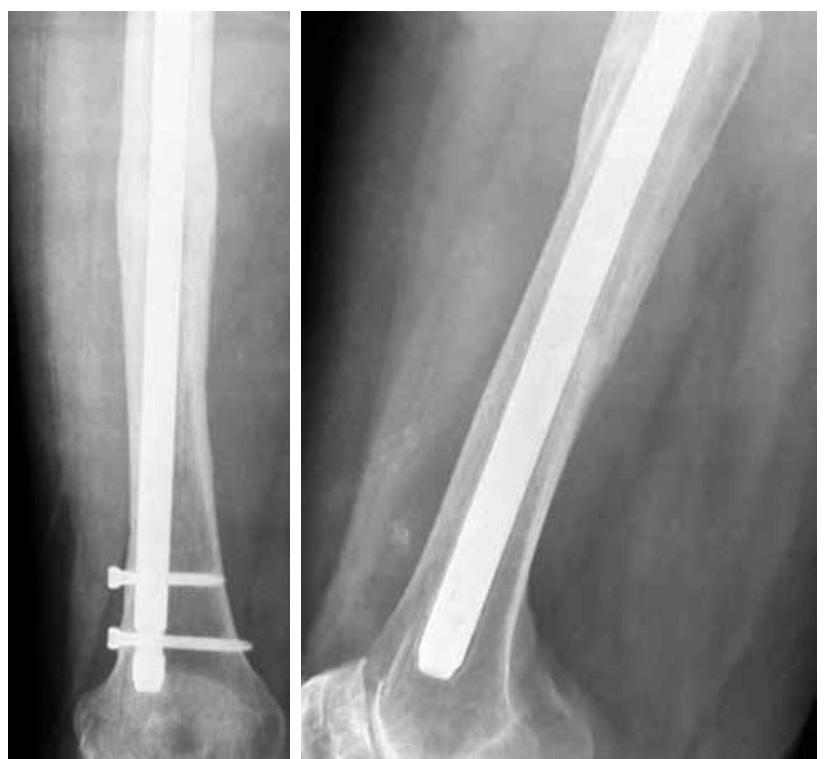

Figure 6. Postoperative anteroposterior and lateral radiograms on second year showing healing fracture of femoral diaphysis.

alendronate treatment for our patients. They are now receiving only calcium and vitamin $\mathrm{D}$ supplementation. After a washout period, we will evaluate our patients again for anti-osteoporotic treatment.

In conclusion, physicians should be aware of the possibility of these rare adverse reactions to the

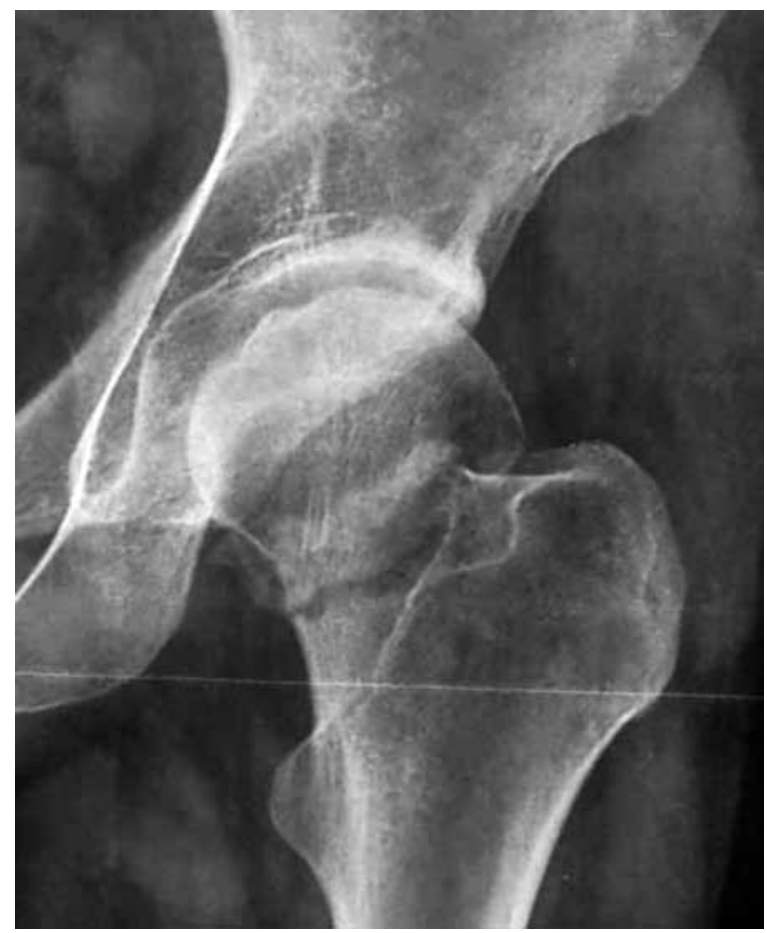

Figure 8. Anteroposterior radiogram showing fracture of femoral neck. 

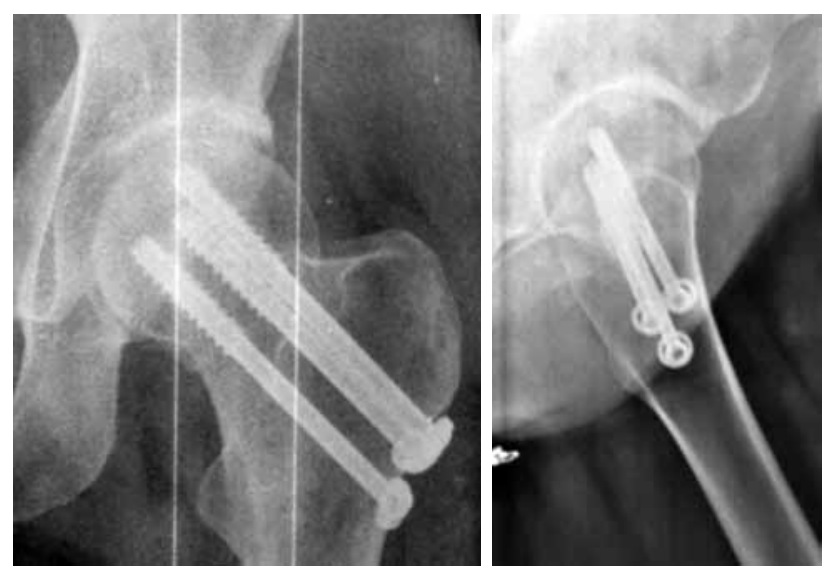

Figure 9. Postoperative anteroposterior and lateral radiograms showing fracture of femoral neck fixed with three canulated screws.
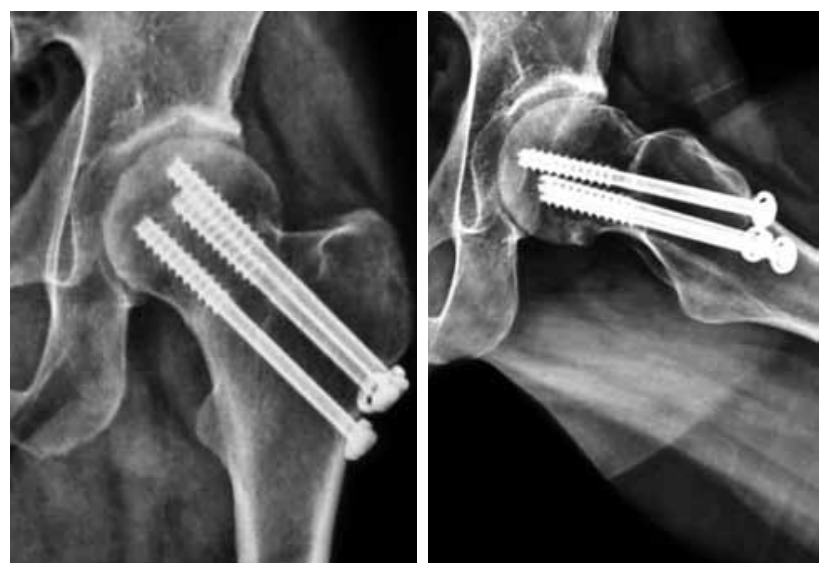

Figure 11. Postoperative anteroposterior and lateral radiograms on seventh month showing healing fracture of femoral neck.

prolonged use of bisphosphonates. We recommend stopping alendronate after five years and following fracture reduction and fixation giving calcium and vitamin D supplements.

In patients on long-term alendronate therapy who present with a subtrochanteric or diaphyseal atypical femoral fracture, we recommend taking radiograms of the contralateral femur. Prophylactic fixation should be considered in patients with a contralateral stress fracture.

\section{Declaration of conflicting interests}

The authors declared no conflicts of interest with respect to the authorship and/or publication of this article.
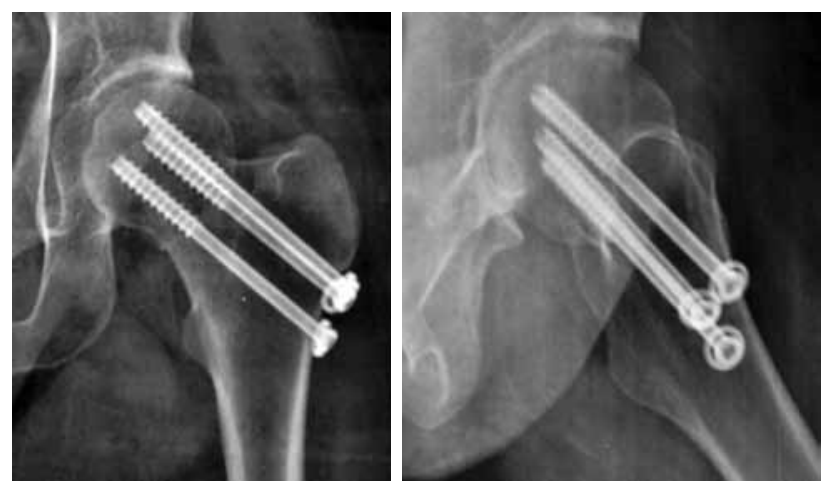

Figure 10. Postoperative anteroposterior and lateral radiograms on second month showing healing fracture of femoral neck.

\section{Funding}

The authors received no financial support for the research and/or authorship of this article.

\section{REFERENCES}

1. GülO, Atik OS, Erdoğan D, Göktaş G, Elmas C. Transmission and scanning electron microscopy confirm that bone microstructure is similar in osteopenic and osteoporotic patients. Eklem Hastalik Cerrahisi 2013;24:126-32.

2. Atik OS, Gunal I, Korkusuz F. Burden of osteoporosis. Clin Orthop Relat Res 2006;443:19-24.

3. Odvina CV, Zerwekh JE, Rao DS, Maalouf N, Gottschalk FA, Pak CY. Severely suppressed bone turnover: a potential complication of alendronate therapy. J Clin Endocrinol Metab 2005;90:1294-301.

4. Atik OS, Suluova F, Görmeli G, Yildirim A, Ali AKh. Insufficiency femoral fractures in patients undergoing prolonged alendronate therapy. Eklem Hastalik Cerrahisi 2010;21:56-9.

5. Weil YA, Rivkin G, Safran O, Liebergall M, Foldes AJ. The outcome of surgically treated femur fractures associated with long-term bisphosphonate use. J Trauma 2011;71:186-90.

6. Grady MK, Watson JT, Cannada LK. Treatment of femoral fracture nonunion after long-term bisphosphonate use. Orthopedics 2012;35:e991-5.

7. Stepan JJ, Burr DB, Pavo I, Sipos A, Michalska D, Li J, et al. Low bone mineral density is associated with bone microdamage accumulation in postmenopausal women with osteoporosis. Bone 2007;41:378-85.

8. Schneider JP. Bisphosphonates and low-impact femoral fractures: current evidence on alendronate-fracture risk. Geriatrics 2009;64:18-23.

9. Edwards BJ, Bunta AD, Lane J, Odvina C, Rao DS, Raisch DW, et al. Bisphosphonates and nonhealing femoral fractures: analysis of the FDA Adverse Event Reporting System (FAERS) and international safety efforts: a systematic review from the Research on Adverse Drug Events And Reports (RADAR) project. J Bone Joint Surg [Am] 2013;95:297-307. 